https://doi.org/10.29013/AJT-19-9.10-49-51

Eshkabilova Mavjuda Ergashboyevna, Doctor of Philosophy in Chemistry (PhD), teacher of Samarkand Construction Institute of Samarkand city, Uzbekistan

Sidikova Xulkar Gulomovna, applicant of the Jazzakh State Institut of Jizzakh city, Uzbekistan

Abduraxmanov Ergashboy, Doctor of Chemical Sciences, professor, Head of the Department of Analytical Chemistry Samarkand State University of Samarkand city, Uzbekistan E-mail:ergash50@yandex.ru

\title{
SELECTIVE THERMOCATALYTIC SENSOR FOR NATURAL GAS MONITORING
}

\begin{abstract}
In the scientific literature and practice, it was traditionally believed that the widely used thermochemical sensors do not provide the selectivity for determining the individual components of a gas mixture. In this work, we developed a sensor for the selective determination of natural gas in the presence of carbon monoxide and hydrogen.

The selectivity of the sensor is ensured using thermosensitive elements with different activity to the components of the gas mixture, differences, the activity of which is ensured by the selection of the composition of the catalyst. In this case, the output signal of the measuring sensor element of the sensor is proportional to the total concentration of the mixture of substances $\left(\mathrm{H}_{2}, \mathrm{CO}\right.$ and $\left.\mathrm{CH}_{4}\right)$, and the output signal of the comparative sensitive element is proportional to the concentration of the mixture of substances $\left(\mathrm{H}_{2}\right.$ and $\left.\mathrm{CO}\right)$ - except for the detected component $\left(\mathrm{CH}_{4}\right)$, and the signal difference is the first and second elements is proportional to the concentration of the determined component $\left(\mathrm{CH}_{4}\right)$ in the mixture.

Keywords: thermocatalytic sensor, selectivity, sensitivity, silver oxide, iron oxide, nickel oxide, carbon monoxide, sol-gel technology, natural gas.

Introduction. Natural gas is one of the most important resources that are actively used in industry and in everyday life. It is almost non-toxic. However, in combination with air at a concentration of from 5.3 to $14.9 \%$ they form an explosive mixture [1]. In this regard, the development of sensors for the rapid determination of natural gas is one of the relevant tasks.

The aim of this work is to develop a sensor providing selective determination of natural gas in the presence of $\mathrm{CO}$ and $\mathrm{H}_{2}$.

It is known that the widely used thermocatalytic sensors (TCS) do not provide selectivity for determining a gas mixture [2]. One of the possible methods for ensuring the selectivity of TCS of combusti-
\end{abstract}


ble gases is the use of heat-sensitive elements (HSE), which have different sensitivity to the components of the gas mixture $[3,4]$. In this regard, the main task in the development of selective TCS for natural gas detection is the selection of catalytic systems of HSE.

Results and discussion. In the temperature range of $100-250^{\circ} \mathrm{C}$ the selectivity of $\operatorname{In}_{2} \mathrm{O}_{3}, \mathrm{Ag}_{2} \mathrm{O}$, $\mathrm{Fe}_{3} \mathrm{O}_{4}$ and $\mathrm{Ni}_{2} \mathrm{O}_{3}$ mixture during the oxidation of combustible gases was studied. As a result of these experiments, it was found that the most optimal for the sensing element of the thermocatalytic sensor of natural gas are the catalyst $0.75 \operatorname{In}_{2} \mathrm{O}_{3}-0.25 \mathrm{Ag}_{2} \mathrm{O}$. It is advisable to use $0.50 \mathrm{Fe}_{3} \mathrm{O}_{4}-0.50 \mathrm{Ni}_{2} \mathrm{O}_{3}$ as a catalyst for the comparative element. Taking into account the specifics of the problem being solved and using the above catalysts, sensors were made for the selective determination of natural gas in the presence of $\mathrm{CO}$ and $\mathrm{H}_{2}$. The sensitive elements of the sensor have the form of a miniature ball of $\gamma$-oxide aluminum inside which there is a spiral of platinum wire (Fig. 1 ), which simultaneously serves as a heating element and a resistance thermometer. Given this, the output signal of the measuring sensor element of the sensor is proportional to the total concentration of the mixture of substances $\left(\mathrm{H}_{2}, \mathrm{CO}\right.$ and $\left.\mathrm{CH}_{4}\right)$, and the output signal of the comparative sensitive element is proportional to the concentration of the mixture of substances $\left(\mathrm{H}_{2}\right.$ and $\left.\mathrm{CO}\right)$ - except for the detected component $\left(\mathrm{CH}_{4}\right)$, and the signal difference is the first and second elements is proportional to the concentration of the determined component $\left(\mathrm{CH}_{4}\right)$ in the mixture.

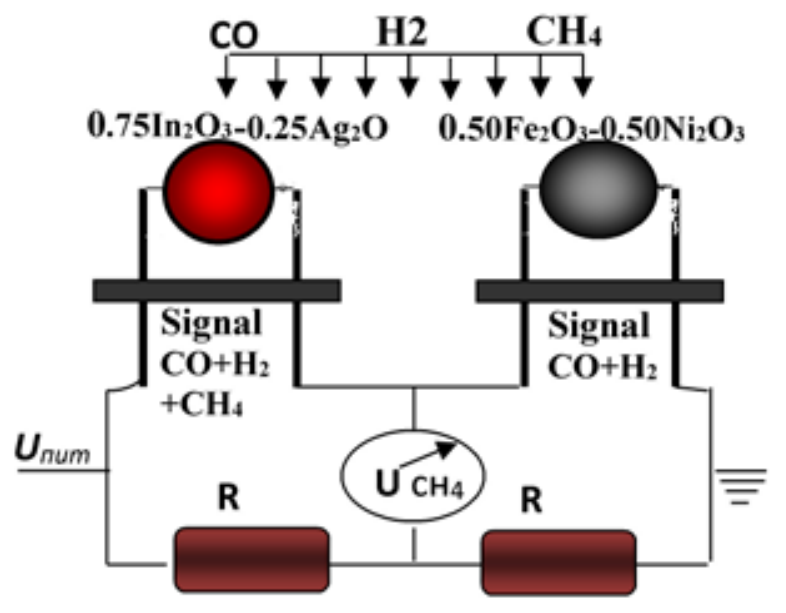

Figure 1. Selective thermocatalytic sensor of natural gas

Tests of the developed sensors included special experiments related to the selection of the supply voltage value, the establishment of calibration characteristics of the sensor, as well as the identification of its degree of selectivity. From the results on the selection of the optimal supply voltage, it follows that the maximum value of the TCS signal with a catalyst $0.75 \mathrm{In}_{2} \mathrm{O}_{3}-0.25 \mathrm{Ag}_{2} \mathrm{O}$ and $0.50 \mathrm{Fe}_{3} \mathrm{O}_{4}-0.50 \mathrm{Ni}_{2} \mathrm{O}_{3}$ when determining natural gas is observed in the range of $2.8-3.0 \mathrm{~V}$.

Table 1.- Sensor signal connection to supply voltage $(n=5, P=0.95)$

\begin{tabular}{|c|c|c|c|c|}
\hline \multirow{2}{*}{ No. } & \multirow{2}{*}{ Sensor supply voltage, $\mathbf{V}$} & \multicolumn{3}{|c|}{ Sensor Signal, $\mathbf{~ m V}$} \\
\cline { 3 - 5 } & 2.5 & $\bar{x} \pm \Delta X$ & $\mathbf{S}$ & $\mathbf{S r}^{-\mathbf{1 0}^{\mathbf{2}}}$ \\
\hline 1. & 2.8 & $20.6 \pm 0.1$ & 0.09 & 1.2 \\
\hline 2. & 3.0 & $27.0 \pm 0.8$ & 0.15 & 1.7 \\
\hline 3. & 3.5 & $28.1 \pm 0.4$ & 0.11 & 1.4 \\
\hline 4. & $25.9 \pm 0.4$ & 0.11 & 1.4 \\
\hline
\end{tabular}


The developed sensor has a response start time $\left(t_{0.1}\right)$ of 3-4 s, a time constant $\left(t_{0.63}\right)$ of no more than $9 \mathrm{~s}$, and a readout time $\left(\mathrm{t}_{0.9}\right)$ of $13 \mathrm{~s}$. The dependence of the TCS signal on the concentration of natural gas in the gas mixture in the studied range (from 0.1 to $5.0 \%$ vol.) of the gas concentration in the air is straight.
The effect of $\mathrm{H}_{2}$ and $\mathrm{CO}$ content on the determined value of the sensor output signal was studied. As follows from the obtained data, TCS with a measuring and compensation element catalyst are characterized by natural gas selectivities in the presence of $\mathrm{H}_{2}$ and $\mathrm{CO}$.

Table 2. - Natural gas sensor selectivity results $(n=5, P=0.95)$

\begin{tabular}{|c|l|c|c|c|}
\hline \multirow{2}{*}{ No. } & \multicolumn{2}{|c|}{ Gas mixture composition,\%vol. } & \multicolumn{3}{c|}{ Natural gas found, vol\% } \\
\cline { 3 - 5 } & & $x \pm \Delta x$ & $\boldsymbol{S}$ & $\boldsymbol{S r}_{\mathbf{1 0}} \mathbf{1 0}^{\mathbf{2}}$ \\
\hline 1. & Natural gas $(0.50)+\operatorname{air}(\mathrm{res})$ & $0.48 \pm 0.06$ & 0.05 & 1.2 \\
\hline 2. & Natural gas $(0.50)+\mathrm{CO}(1.00)+$ air(res $)$ & $0.52 \pm 0.03$ & 0.03 & 1.6 \\
\hline 3. & Natural gas $(0.50)+\mathrm{H}_{2}(1.00)+$ air(res $)$ & $0.51 \pm 0.03$ & 0.04 & 1.7 \\
\hline
\end{tabular}

The error of the sensors due to unmeasured components in gas mixtures does not exceed $2.0 \%$.

Conclusion. In summary, a highly sensitive sensor has been developed which allows to selectively detect natural gas from a mixture of combustible substances. The developed sensor is used to measure pre-explosive concentrations of natural gas in atmospheric air.

\section{Список митературы:}

1. Бесчастнов М. В. Промышиенные взрывы. Оценка и предупреждение.- М., Химия, 1991.

2. Карпов Е. Ф. Автоматическая газовая защита и контроль рудничной ат-мосферы / Карпов Е. Ф., Биренберг И.Э., Басовский Б. И.-М.: НеАра, 1984.- 285 с.

3. АбАурахманов Э., Рузиев Э.А. Селективные термокаталитические сенсоры в экоаналитическом мониторинге газообразных выбросов // Химическая промышиенность,- С-Пб., 2003.- Т. 80.№ 9.- С. 19-25.

4. Эшкобимов Ш. А., Эшкобимова М. Э. АбАурахманов Э. Катализатор дмя селективного термокаталитического сенсора природного газа / Ж Журнал «Химическая промышленность» Россия. 2015. 5 с. 